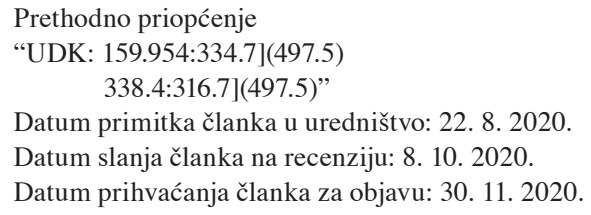

Jelena Manojlović, mag. oec. ${ }^{1}$

Doc. dr. sc. Morana Fudurić ${ }^{2}$

\title{
POVEZANOST ORIJENTACIJE NA PROIZVOD I ORIJENTACIJE NA KUPCA S PERCIPIRANOM INOVATIVNOSTI PROIZVODA ZA KUPCA I USPJEŠNOSTI PODUZEĆA U KREATIVNIM I KULTURNIM INDUSTRIJAMA
}

\section{THE RELATIONSHIP BETWEEN PRODUCT AND CUSTOMER ORIENTATION AND PERCEIVED PRODUCT INNOVATION AND COMPANY PERFORMANCE IN CREATIVE AND CULTURAL INDUSTRIES}

SAŽETAK: Kreativne i kulturne industrije (KKI) promoviraju se kao važna komponenta ,novih gospodarstava“ koja će potaknuti budući gospodarski rast, što se prema hrvatskim podacima o BDP-u u periodu od 2009. do 2013. i potvrdilo. One su jedine koje su imale rast BDP-a za vrijeme krize. Ovaj rad se bavi proučavanjem povezanosti strateške orijentacije na proizvod i na kupca s percipiranom inovativnosti proizvoda za kupca te percipiranom uspješnosti poduzeća u kreativnim i kulturnim industrijama u Republici Hrvatskoj. Provedeno je kvantitativno istraživanje na namjernom prigodnom uzorku zaposlenika poduzeća koja djeluju u sklopu KKI. U istraživanju su se koristile postojeće skale, dok je instrument istraživanja bio visokostrukturirani anketni upitnik distribuiran elektroničkim putem. Rezultati istraživanja su pokazali da inovativnost proizvoda za kupca i orijentacija na kupca imaju statistički značajan pozitivni utjecaj na percipiranu uspješnost poduzeća u KKI.

KLJUČNE RIJEČI: strateška orijentacija, orijentacija na proizvod, orijentacija na kupca, kreativne i kulturne industrije, inovativnost proizvoda, uspješnost poduzeća

ABSTRACT: Creative and cultural industries (CCI) are being promoted as an important component of "new economies" that will stimulate future economic growth, which

\footnotetext{
${ }^{1}$ Jelena Manojlović, mag. oec., Bolton Croatia, Savska Opatovina 36, 10000 Zagreb

${ }^{2}$ Doc. dr. sc. Morana Fudurić, Ekonomski fakultet - Zagreb, Trg J. F. Kennedyja 6, 10000 Zagreb, Hrvatska
} 
has also been confirmed by the trends in the Croatian GDP data from 2009 to 2013 . CCI was the only industry branch that recorded GDP growth during the global economic crisis. This paper examines the impact of strategic orientations, namely the product orientation and customer orientation on perceived product newness to customers and perceived company performance in creative and cultural industries (CCI) in Croatia. Quantitative research was conducted on a purposive sample of employees of companies operating within the CCI. Existing measurement scales were used in a highly structured questionnaire that was distributed electronically. The results indicate that product newness to customers and customer orientation have a statistically significant positive impact on perceived company performance in CCI.

KEY WORDS: strategic orientation, product orientation, customer orientation, creative and cultural industries, product newness, company performance

\section{UVOD}

Strateška orijentacija poduzeća odražava strateške pravce koje poduzeće provodi kako bi stvorilo odgovarajuća ponašanja s ciljem ostvarivanja kontinuirano superiornog poslovanja (Narver i Slater, 1990.; Gatignon i Xuereb, 1997.). U tom kontekstu, u literaturi se kao bitan čimbenik za uspješnost novih proizvoda, ali i poduzeća u cjelini, najčešće navode tržišna orijentacija, orijentacija na kupca, orijentacija na proizvod (odnosno tehnološka orijentacija) i orijentacija na konkurenciju (Narver i Slater, 1990., Jaworski i Kohli, 1993., Gatignon i Xuereb, 1997., Atuahene-Gima, 1995., Matsuno i Mentzer, 2000., Voss i Voss, 2000., Noble et al., 2002.). Strateška orijentacija na kupca dovodi do boljeg razumijevanja kupaca, što dovodi do povećanja zadovoljstva kupaca te uspješnijeg poslovanja. Usprkos tome, Gatignon i Xuereb (1997.) i Voss i Voss (2000.) upozoravaju da kontinuirana usmjerenost na kupca može dovesti do inercije te se za razvoj novih, inovativnih proizvoda sugerira primjena strateške orijentacije na proizvod.

Iako se velik broj znanstvenih radova bavi proučavanjem utjecaja strateške orijentacije na uspješnost poduzeća (Slater i Narver, 1994., Gatignon i Xuereb 1997., Jaworski i Kohli 1993., Hult i Ketchen, 2001.), pregledom dosadašnje literature može se ustvrditi da dosad nije istražen utjecaj strateške orijentacije poduzeća koja djeluju u sklopu kreativnih i kulturnih industrija jedne države, pogotovo kada je riječ o Republici Hrvatskoj. Također, nedovoljno je istražen odnos između različitih strateških orijentacija, percipirane inovativnosti proizvoda za kupca i uspješnosti poduzeća.

Sukladno tome, predmet i cilj ovog rada jest produbiti postojeće spoznaje o utjecaju strateške orijentacije na uspješnost poduzeća u kreativnim i kulturnim industrijama (u nastavku rada KKI). Kreativne i kulturne industrije u Republici Hrvatskoj sustavno se prate tek od 2013. godine te od tada počinju poprimati sve veću važnost u gospodarstvu Republike Hrvatske. Prilikom istraživanja utjecanja strateške orijentacije, promatrat će se utjecaj dviju strateških orijentacija - orijentacije na kupca i orijentacije na proizvod - na percipiranu inovativnost proizvoda za kupca te na percipiranu uspješnost poduzeća koja djeluju u sklopu KKI.

Ostatak rada organiziran je kako slijedi. Teorijski okvir donosi pregled literature vezane za stratešku orijentaciju usmjerenu na kupca i stratešku orijentaciju usmjerenu na 
proizvod te pregled dosadašnjih znanstvenih istraživanja iz tog područja. Također obuhvaća definiciju i razvoj kulturnih i kreativnih industrija, njihove specifičnosti, karakteristike proizvoda te kulturne i kreativne industrije na području Hrvatske. Istraživački dio rada prikazuje dizajn i metodologiju istraživanja, analizu rezultata temeljem kojih se izvode zaključna razmatranja te ograničenja i preporuke za buduća istraživanja.

\section{TEORIJSKI OKVIR ISTRAŽIVANJA}

\subsection{Strateška orijentacija}

Prema Gatignon i Xuereb (1997.) strateška orijentacija je multidimenzionalni konstrukt koji se sastoji od: (1) orijentacije na kupca, (2) orijentacije na konkurente i (3) tehnološke orijentacije. Uz navedene orijentacije Gatignon i Xuereb navode i interfunkcionalnu koordinaciju kao jedan od mehanizama koji omogućuje sinergijski učinak prethodno navedene tri strateške orijentacije.

Orijentacija na kupca često se poistovjećuje s tržišnom orijentacijom (engl. market ili marketing orientation) (Kohli i Jaworski 1990., 1993.; Deshpandé, Farely i Webster 1993.; Shapiro 1988.) uz argument da poduzeća koja primjenjuju orijentaciju na kupca i tržišnu orijentaciju fokus stavljaju upravo na potrošača. S druge strane, Narver i Slater (1990.) navode da se orijentacija na kupca i tržišna orijentacija ne mogu promatrati kao sinonimi (vidjeti i Slater i Narver, 1999.). Navedeni autori tvrde da se tržišna orijentacija sastoji od orijentacije na kupca, orijentacije na konkurente i međukulturalne koordinacije, pri čemu orijentacija na kupca podrazumijeva kontinuirano razumijevanje i pružanje dodatne vrijednosti ciljnoj grupi potrošača. Gatignon i Xuereb (1997.) na sličan način definiraju orijentaciju na kupca kao proces identificiranja, analize, razumijevanja i odgovora na potrebe potrošača. Svako poduzeće orijentirano na potrošače sagledava sadašnje, ali i buduće potrošače te je cilj njihovog poslovanja zadovoljavati trenutne potrebe i želje te anticipirati one buduće. Takva analiza zahtijeva stalno praćenje promjenjivih potreba i želja potrošača kako bi se dugoročno ostvarili dobri poslovni rezultati. Pritom informacije prikupljene od potrošača s kojima poduzeće ima uspješnu suradnju vrlo vjerojatno neće moći poslužiti za razvoj složenijih inovacija koje bitno odstupaju od postojećih proizvoda na tržištu (Božić, 2006.).

Usprkos uvriježenom mišljenju da je za uspješnost proizvoda važno zadovoljiti želje i potrebe potrošača, neki autori ističu da kontinuirani fokus na potrošača može dovesti do inercije (Christensen i Bower, 1996.) te sugeriraju da je za razvoj istinski inovativnih proizvoda potrebno zanemariti želje i potrebe potrošača (Martin 1995., Voss i Voss, 2000.). Sukladno tome, javlja se orijentacija na proizvod (ili tehnološka orijentacija) pri čemu se poduzeće obvezuje na integraciju inovacija u razvoj novih proizvoda i marketinške procese (Voss i Voss, 2000.). Drugim riječima, poduzeća koja su orijentirana na proizvod odlikuju se sposobnošću i voljom da steknu značajnu tehnološku podlogu i koriste ju u razvoju novih proizvoda s ciljem postizanja veće konkurentske prednosti kroz što veći stupanj diferencijacije od drugih konkurentnih proizvoda na tržištu (Gatignon i Xuereb, 1997.). Navedeno znači da će sve unutar poduzeća biti usmjereno i podređeno stvaranju i isporučivanju inovativnog i superiornog proizvoda ili usluge. To može, primjerice, uz kontinuirano poboljšanje 
proizvoda uključivati i bržu ili bolju isporuku, jednostavniji pristup uputama/instrukcijama o upotrebi proizvoda odnosno, sve dodatne aktivnosti koje će unaprijediti specifičan proizvod ponuđen tržištu. Poduzeće koje je odabralo takvu strategiju ulagat će u proizvodnju i poboljšanje performansi proizvoda te testiranje kako bi u konačnici osigurali planirani životni ciklus proizvoda. Orijentacija na proizvod često se veže uz inovacije te uz poduzeća koja su orijentirana na istraživanje i razvoj (Gatignon i Xuereb, 1997.). Cooper (1994.) na sličan način opisuje tehnološki vođene organizacije koje su proaktivne i koriste specifične tehnologije u razvoju novih proizvoda.

Zaključno, orijentacija na proizvod kroz tehnološko usavršavanje nudi novi i drugačiji odgovor na potrebe potrošača koji orijentacija na kupca ne može ponuditi jer se temelji na željama i potrebama iskazanim na tržištu. Gatignon i Xuereb (1997.) ističu da primjena orijentacije na proizvod dovodi do razvoja radikalnih inovacija te posljedično i veće konkurentske prednosti. Otkrivanjem radikalnih inovacija potrebno je snažno tehnološko znanje i menadžment te jasna tehnološka, tj. proizvodna strategija (Porter, 1985.). S druge strane, orijentacija na kupca više je okrenuta atraktivnosti na tržištu, kao što su niske cijene, brza priprema, jednostavnost kupnje, a ne toliko funkcionalnosti ili kvaliteti, kao što je orijentacija na proizvod.

\subsection{Utjecaj strateške orijentacije na uspješnost poduzeća}

Pregledom literature iz područja utvrđen je veliki broj radova koji istražuju posljedice primjene strateške orijentacije koje se mogu grupirati u četiri osnovne skupine: (1) posljedice za poduzeće (npr. razni objektivni i subjektivni pokazatelji uspješnosti poduzeća odnosno organizacije), (2) posljedice za kupce (npr. percipirana kvaliteta, zadovoljstvo kupaca i lojalnost), (3) posljedice za inovativnost (npr. stupanj inovativnosti i uspješnost novih proizvoda) i (4) posljedice za zaposlenike (npr. zadovoljstvo poslom i predanost poslu). Kirca et al. (2005.) pritom ističu da se većina istraživanja fokusira na utvrđivanje utjecaja strateške orijentacije na posljedice za poduzeće, što je ujedno i cilj ovog rada te će detaljnije biti pojašnjeno u nastavku.

Primjerice, dio autora istražuje utjecaj strateških orijentacija na objektivne pokazatelje uspješnosti poduzeća poput tržišnog udjela (Jaworski i Kohli, 1993.), prihoda od prodaje (Jaworski i Kohli, 1993., Voss i Voss, 2000.) ili različitih pokazatelja profitabilnosti (Han et al., 1998., Noble et al., 2002.). S druge strane, veći dio istraživanja koristi subjektivne pokazatelje poput percipirane općenite uspješnosti poduzeća (Jaworski i Kohli, 1993., Voss i Voss, 2000., Camarero i Garrido, 2008.), percipiranog tržišnog udjela, rasta prodaje i povrata na ulaganje (ROI) (Matsuno i Mentzer, 2000.) ili percipirane uspješnosti novog proizvoda na tržištu koja se mjerila kroz relativan percipirani ROI, tržišni udio, prodaju i profitne ciljeve (Gatignon i Xuereb, 1997., Atuahene-Gima, 1995., 1996.).

Atuahene-Gima (1995.) istražuje utjecaj tržišne orijentacije na uspješnost novog proizvoda i moderatorski učinak karakteristika inovacija (inkrementalne nasuprot radikalnim inovacijama proizvoda za kupca i za poduzeće). Prema rezultatima istraživanja marketinška orijentacija ima značajan pozitivan utjecaj na uspješnost novog proizvoda. Međutim, jačina utjecaja tržišne orijentacije na uspješnost novog proizvoda varira ovisno o tome predstavlja li taj proizvod inkrementalnu ili radikalnu inovaciju za kupca i poduzeće. Suprotno njiho- 
vom očekivanju, rezultati su pokazali da tržišna orijentacija ima jači utjecaj na uspješnost novog proizvoda ukoliko se radi o manjim odnosno inkrementalnim inovacijama.

Gatignon i Xuereb (1997.) smatraju da strateška orijentacija može imati i direktan utjecaj na karakteristike inovacija promatrane kroz inkrementalnost/radikalnost inovacije, prednosti proizvoda i troškove proizvoda. Zaključuju da je za razvoj superiornih inovacija nužna orijentacija na proizvod. Međutim, također ističu da poduzeća trebaju kombinirati orijentaciju na kupca i orijentaciju na proizvod kako bi postigli veću uspješnost poduzeća u situacijama nesigurne potražnje na tržištu.

Voss i Voss (2000.) istražuju utjecaj strateške orijentacije na proizvod i na kupca na uspješnost organizacije na primjeru neprofitne kazališne ustanove. U istraživanju koriste objektivne mjere uspješnosti poput posjećenosti kazališta, ukupnog prihoda od prodaje karata i neto dobiti te subjektivne mjere poput menadžerske percepcije uspješnosti. Autori su temeljem istraživanja zaključili da: (1) orijentacija na proizvod ima pozitivan utjecaj na uspješnost poduzeća i jačanje korisničke baze te na percipiranu uspješnost; (2) orijentacija na konkurenciju pozitivno utječe na posjećenost te ima negativan učinak na dobit/gubitak; i (3) orijentacija na kupca negativno utječe na potrošače koji imaju godišnju pretplatu na događanja, ukupni prihod i neto dobit/gubitak, a od subjektivnih mjera ima negativan utjecaj na percipiranu uspješnost kazališta. Rezultati ukazuju na to da se povezanost između strateške orijentacije i uspješnosti poduzeća razlikuje ovisno o vrsti korištene mjere uspješnosti. Međutim, najzanimljiviji rezultat je da orijentacija na potrošača pokazuje negativnu povezanost s prodajom ulaznica pretplatnika, ukupnim prihodima i neto dobiti/gubitkom.

Naposljetku, Camarero i Garrido (2008.) promatraju utjecaj tržišne orijentacije i orijentacije na proizvod na ekonomsku i društvenu uspješnost muzeja. Rezultati ukazuju da orijentacija na proizvod ima najveći, statistički značajan, pozitivan utjecaj na društvenu uspješnost muzeja, kao i orijentacija na kupca i interfunkcionalna koordinacija. Orijentacija na kupca i interfunkcionalna koordinacija imaju i pozitivan utjecaj na ekonomsku uspješnost muzeja, dok orijentacija na proizvod ima posredan utjecaj na ekonomsku uspješnost muzeja.

\subsection{Kreativne i kulturne industrije}

Kreativne i kulturne industrije poprimaju sve veću važnost i interes kako javnosti tako i struke. Prema izvještaju UN-a o kreativnoj ekonomiji iz 2010. pravilno njegovana kreativnost hrani kulturu, pospješuje ljudski rast i razvoj te je glavni pokretač u stvaranju novih radnih mjesta, inovacija i trgovine, a ujedno potiče socijalnu uključenost, kulturnu raznolikost i održivost.

Usprkos rastućem interesu i važnosti KKI, pregledom vezane literature ne može se pronaći jedinstvena definicija iste. Pojam kreativnih industrija koristi se kada govorimo o filmu, modi, dizajnu, umjetnosti, arhitekturi i mnogim ostalim aktivnostima koje čine svakodnevni dio našeg života. Često se pojam kreativnih industrija poistovjećuje i naziva kulturnim industrijama ili kreativnom ekonomijom. No navedeni pojmovi se razlikuju; kreativna ekonomija podrazumijeva procese proizvodnje, distribucije i potrošnje (nematerijalnih) kreativnih, kulturnih i simboličkih dobara uključujući iskustva, percepcije, slike, ideje, softver, medijske sadržaje, dizajn, informacije i usluge (Primorac, 2012.), a kada govorimo 
o kulturnim industrijama, govorimo o onima koje obuhvaćaju proizvodnju simboličkih dobara, njihovu reprodukciju i distribuciju dok pojam kreativnih industrija obuhvaća pojam kulturnih industrija iako potječu iz različitog konteksta. Uz navedene pojmove koriste se i pojmovi industrije autorskih prava, industrije zabave, ponekad se povezuju i s industrijama slobodnog vremena, medijskim industrijama ili industrijama sadržaja (content industries). U žargonu se koriste i izrazi sunrise ili future-oriented industries (Jovičić i Mikić, 2006.). U današnje vrijeme pojam kulturnih industrija najčešće se koristi za industrije koje stvaraju kulturna dobra i usluge, ali ponekad se koristi i u kontekstu vezanom uz njegove korijene; oprečnosti kvalitetno/nekvalitetno, masovno/jedinstveno, popularno/profinjeno i sl.

Britanski DCMS (Department of Culture, Media and Sport) 1998. godine objavljuje jednu od najpoznatijih definicija kreativnih industrija (tzv. UK DCMS model): „one aktivnosti koje imaju korijen u individualnoj kreativnosti, znanju i talentu te imaju potencijal za blagostanje i kreiranje novih radnih mjesta proizvodnjom i eksploatacijom intelektualnog vlasništva“ (DCMS, 1998:3). Trenutna DCMS definicija obuhvaća 13 kreativnih sektora; oglašavanje, arhitektura, umjetnost, obrt, dizajn, moda, film i video, interaktivni softveri za zabavu, glazba, izvedbene umjetnosti, izdavaštvo, televizija, radio (UK Department of Culture, Media and Sport, The Creative Industries Mapping Document 2001., London: DCMS 2001.). U širem smislu obilježja kreativnih industrija su snažan rast, inovacije i kreativnost te konstantan fokus na zahtjevima potrošača (DCMS, 2007.).

Prvi pokušaj sustavnog praćenja kulturnih i kreativnih industrija u Hrvatskoj bio je u Studiji Državnog zavoda za intelektualno vlasništvo Republike Hrvatske 2007. godine. Studija je prikazala ekonomski doprinos i važnost industrija autorskih prava u RH u periodu od 2002. do 2004. No veću važnost KKI dobivaju osnivanjem Hrvatskog klastera konkurentnosti kreativnih i kulturnih industrija - HKKKKI osnovanog prema inicijativi Ministarstva gospodarstva 2013. godine. Temeljem mapiranja KKI u Hrvatskoj obuhvaćaju 45 djelatnosti (razina razreda NKD-a 2007) grupiranih u 12 pod-sektora. Prema izvješću Ekonomskog Instituta Zagreb iz 2016. godine 43 djelatnosti su potpuno kreativne, a dvije su djelomično kreativne. Podjela na 12 pod-sektora definirana je od strane Hrvatskog klastera konkurentnosti kreativnih i kulturnih industrija (HKKKKI) te je dostupna u Prilogu 1.

Hesmondhalgh (2008.) i Throsby (2003.) ističu da specifičnosti KKI proizlaze iz kontinuiranog viška ponude kreativnog rada na tržištu i to neovisno o ekonomskim ciklusima. Sukladno navedenom, višak ponude kreativnih usluga i dobara rezultirat će uspjehom manjeg broja proizvoda na tržištu. Posljedično, za svaki proizvod postoji veliki stupanj nesigurnosti vezan za uspjeh na tržištu (De Vany i Walls, 2004., Pratt 2008.) jer prije konzumacije potrošači nemaju nikakvo znanje o proizvodu (Towse, 2003.). Nastavno na navedeno, Peltoniemi (2015.) kao specifičnost KKI navodi balans između stupnja noviteta i prethodnog poznavanja određenog proizvoda. Potrošači traže određenu dozu poznavanja proizvoda kako bi ga razumjeli i samim time znali ga koristiti, a s druge strane potrebni su im i noviteti koji potiču interes za otkrivanjem (Alvarez et al. 2005.). Dobar primjer su filmovi nastali prema knjigama koji ostvaruju bolje rezultate u odnosu na druge, upravo zbog određene razine prethodnog poznavanja proizvoda. 


\section{EMPIRIJSKO ISTRAŽIVANJE UTJECAJA STRATEŠKE ORIJENTACIJE NA INOVATIVNOST PROIZVODA ZA KUPCA I PERCIPIRANU USPJEŠNOST PODUZEĆA}

\subsection{Dizajn i metodologija istraživanja}

Kako bi se utvrdio utjecaj strateških orijentacija na karakteristike proizvoda i percipiranu uspješnost poduzeća (Prikaz 1.) provedeno je jednokratno deskriptivno istraživanje na uzorku zaposlenika poduzeća koja djeluju u sklopu KKI u Republici Hrvatskoj. Prikazani model predstavlja nadogradnju istraživanja Atuahene-Gima (1995., 1996.), Gatignon i Xuereb (1997.) i Voss i Voss (2000.) detaljnije opisanih u poglavlju 2.2. ovog rada.

Prikaz 1. Model utjecaja strateških orijentacija na inovativnost proizvoda za kupca i percipiranu uspješnost poduzeća

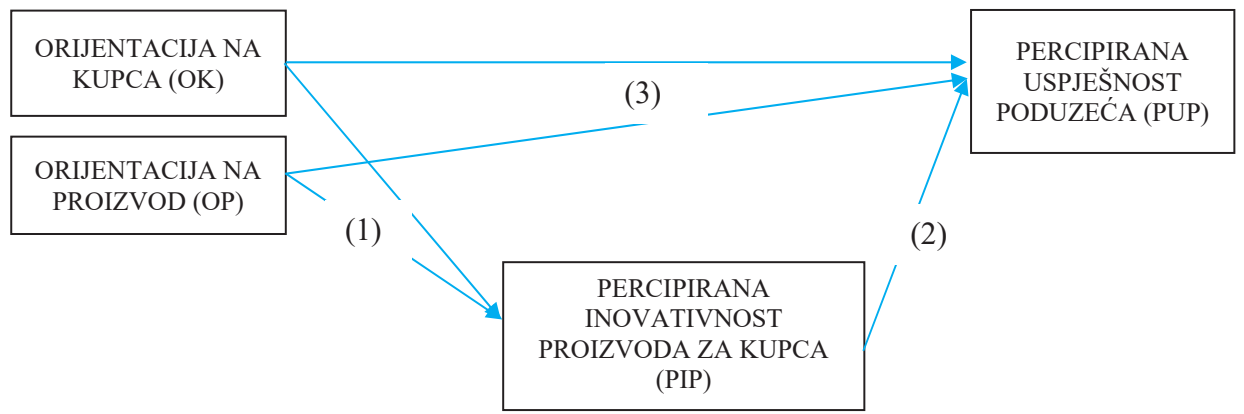

Izvor: izrada autorica.

Model se može prikazati i sljedećim regresijskim jednadžbama:

$$
\mathrm{Y}_{(\mathrm{PIP})}=\alpha+\beta_{I} x_{l(O K)}+\beta_{2} x_{2(O P)}+e_{i}
$$

$\mathrm{Y}_{(\mathrm{PIP})}$ - percipirana inovativnost proizvoda za kupca

$\alpha-$ konstantni član

$\beta_{1}$ - regresijski koeficijent koji prikazuje promjenu percipirane inovativnosti proizvoda za kupca uslijed povećanja orijentacije na kupca za jedan stupanj na Likertovoj ljestvici

$\beta_{2}$ - regresijski koeficijent koji prikazuje promjenu percipirane inovativnosti proizvoda za kupca uslijed povećanja orijentacije na proizvod za jedan stupanj na Likertovoj ljestvici

$x_{1(\mathrm{OK})}-$ orijentacija na kupca

$x_{2(O P)}$ - orijentacija na proizvod

$$
\mathrm{Y}_{(\mathrm{PUP})}=\alpha+\beta x_{(P I P)}+e_{i}
$$

$\mathrm{Y}_{\text {(PUP) }}$ - percipirana uspješnost poduzeća 
$\alpha-$ konstantni član

$\beta_{I}-$ regresijski koeficijent koji prikazuje promjenu percipirane uspješnosti poduzeća uslijed povećanja percipirane inovativnosti proizvoda za kupca za jedan stupanj na Likertovoj ljestvici

$x_{l(P I P)}-$ percipirana inovativnost proizvoda za kupca

$$
\mathrm{Y}_{(\mathrm{PUP})}=\alpha+\beta_{I} x_{1(\mathrm{OK})}+\beta_{2} x_{2(O P)}+e_{i}
$$

$\mathrm{Y}_{(\mathrm{PUP})}$ - percipirana uspješnost poduzeća

$\alpha-$ konstantni član

$\beta_{1}-$ regresijski koeficijent koji prikazuje promjenu percipirane uspješnosti poduzeća uslijed povećanja orijentacije na kupca za jedan stupanj na Likertovoj ljestvici

$\beta_{2}-$ regresijski koeficijent koji prikazuje promjenu percipirane uspješnosti poduzeća uslijed povećanja orijentacije na proizvod za jedan stupanj na Likertovoj ljestvici

$x_{1(\mathrm{OK})}-$ orijentacija na kupca

$x_{2(O P)}-$ orijentacija na proizvod.

Instrument istraživanja. Istraživanje je provedeno putem visokostrukturiranog anketnog upitnika koji je distribuiran elektroničkim putem. Anketni upitnik se sastojao od 4 dijela. Prvi dio odnosio se na orijentaciju na proizvod i orijentaciju na kupca. Orijentacija na proizvod mjerila se trima česticama uz korištenje Likertove skale od sedam stupnjeva (1 uopće se ne slažem, 7 - u potpunosti se slažem) prema Voss i Voss (2000.). Orijentacija na kupca također se mjerila trima česticama uz korištenje Likertove skale od sedam stupnjeva (1 - uopće se ne slažem, 7 - u potpunosti se slažem) prema Voss i Voss (2000.). Percipirana inovativnost proizvoda za kupca mjerila se korz sedam čestica prilagođenih prema Atuahene-Gima (1996.) i Eliashberg i Robertson (1988.) na Likertovoj skali od sedam stupnjeva ( 1 - uopće se ne slažem, 7 - u potpunosti se slažem). Percipirani uspjeh poduzeća mjerio se dvjema česticama prema Jaworski i Kohli (1993.) na Likertovoj skali od pet stupnjeva (1 - uopće se ne slažem, 5 - u potpunosti se slažem). Razlike u stupnjevima Likertove skale u skladu su s preporukama MacKenzie i Podsakoff (2012.) s ciljem smanjivanja pristranosti zbog primjene uobičajenih metoda u istraživanjima iz područja marketinga. Sve mjerne skale imale su stupanj pouzdanosti Cronbach Alpha iznad 0,70 sukladno preporukama Nunnally (1994.). Na kraju upitnika uslijedila su pitanja vezana uz socio-demografske karakteristike ispitanika poput spola, dobi, stupnja obrazovanja, pozicije u poduzeću i djelatnosti poduzeća.

Uzorak istraživanja i proces prikupljanja podataka. Kako bi se istražio utjecaj strateške orijentacije na inovativnost proizvoda za kupca i uspješnost poduzeća, podaci su prikupljani od zaposlenika poduzeća koja djeluju u sklopu KKI u Republici Hrvatskoj. Pritom je korišten namjerni prigodni uzorak ispitanika. Poziv za sudjelovanje i ispunjavanje anketnog upitnika poslan je na 300 poslovnih e-mail adresa javno dostupnih istraživačima. Poziv je sadržavao zamolbu za popunjavanje upitnika, objašnjenje predmeta i ciljeva istraživanja, poveznicu na elektroničku verziju upitnika te kontakte istraživača. Sudjelovanje u istraživanju bilo je u potpunosti dobrovoljno i anonimno te je sudionicima omogućeno odustajanje u bilo kojoj fazi ispunjavanja anketnog upitnika. 
J. Manojlović, M. Fudurić: Povezanost orijentacije na proizvod i orijentacije na kupca...

Tablica 1. Socio-demografske karakteristike ispitanika

\begin{tabular}{|c|c|c|c|}
\hline Obilježje & Kategorija & Frekvencija & Postotak \\
\hline \multirow{2}{*}{ Spol } & M & 36 & $45.00 \%$ \\
\hline & $\check{Z}$ & 44 & $55.00 \%$ \\
\hline \multirow{5}{*}{ Dob } & $18-24$ & 3 & $3.75 \%$ \\
\hline & $25-34$ & 57 & $71.25 \%$ \\
\hline & $35-44$ & 13 & $16.25 \%$ \\
\hline & $45-54$ & 3 & $3.75 \%$ \\
\hline & $55-65$ & 4 & $5.00 \%$ \\
\hline \multirow{8}{*}{ Stupanj obrazovanja } & SSS & 8 & $10.00 \%$ \\
\hline & VŠS & 2 & $2.50 \%$ \\
\hline & Struč. bacc. oec. & 3 & $3.75 \%$ \\
\hline & Bacc. oec. & 6 & $7.50 \%$ \\
\hline & MBA & 3 & $3.75 \%$ \\
\hline & Mag. oec. & 50 & $62.50 \%$ \\
\hline & Univ. spec. oec. & 1 & $1.25 \%$ \\
\hline & Mr. sc. & 7 & $8.75 \%$ \\
\hline \multirow{4}{*}{ Pozicija u poduzeću } & Direktor & 9 & $11.25 \%$ \\
\hline & Menadžerska funkcija & 10 & $12.50 \%$ \\
\hline & Samozaposlen/a & 15 & $18.75 \%$ \\
\hline & Ostalo & 46 & $57.50 \%$ \\
\hline \multirow{12}{*}{ Djelatnost } & $\begin{array}{c}\text { Oglašavanje i tržišne } \\
\text { komunikacije }\end{array}$ & 17 & $21,25 \%$ \\
\hline & Računalni programi, igre i novi mediji & 14 & $17,50 \%$ \\
\hline & Umjetnost & 14 & $17,50 \%$ \\
\hline & Muzeji, knjižnice i baština & 9 & $11,25 \%$ \\
\hline & Dizajn & 6 & $7,50 \%$ \\
\hline & Glazba i izvedbene umjetnosti & 5 & $6,25 \%$ \\
\hline & Arhitektura & 4 & $5,00 \%$ \\
\hline & Elektronički mediji & 4 & $5,00 \%$ \\
\hline & Fotografija & 3 & $3,75 \%$ \\
\hline & Izdavaštvo & 2 & $2,50 \%$ \\
\hline & Film & 1 & $1,25 \%$ \\
\hline & Zanati (umjetnički i tradicijski obrti) & 1 & $1,25 \%$ \\
\hline
\end{tabular}

Izvor: obrada autorica (SPSS). 
Distribucija anketnog upitnika elektroničkim putem odabrana je zbog ograničenih financijskih i ljudskih resursa te velike geografske raspršenosti potencijalnih sudionika istraživanja sukladno preporukama Aaker et al. (2016.). Također, obzirom da se pitanja u upitniku odnose na strateške odluke poduzeća, karakteristike proizvoda te percipiranu uspješnost poduzeća, ovakav način prikupljanja podataka daje ispitanicima dovoljno vremena da razmisle te po potrebi konzultiraju dodatne interne materijale kako bi pružili što kvalitetnije odgovore.

Metode korištene za statističku analizu podataka su deskriptivna statistička analiza (mjere centralne tendencije, mjere varijabiliteta i mjere oblika) i inferencijalna statistika (parametrijski testovi). U istraživanju je sudjelovalo 80 ispitanika zaposlenih u KKI uz stopu povrata od 26,66 \%. Socio-demografske karakteristike ispitanika prikazane su u Tablici 1.

Uzorkom je obuhvaćeno 36 muških (45 \%) ispitanika i 44 ženskih (55\%) ispitanika. Većina ispitanika je između 25 i 34 godina starosti $(71,25 \%)$, potom slijedi skupina ispitanika između 35 i 44 godina starosti $(16,25 \%)$, a preostali starosni razredi ispitanika bili su relativno podjednako distribuirani. Gotovo dvije trećine ispitanika bilo je onih sa završenim stupnjem magistra struke $(62,50 \%)$, a $11,25 \%$ ispitanika obnašalo je direktorsku funkciju u poduzeću, $12,50 \%$ njih obnašalo je neku od menadžerskih funkcija, a 18,75 \% bilo ih je samozaposleno odnosno u nekom obliku poduzetničke djelatnosti. Najzastupljenija djelatnost je oglašavanje i tržišne komunikacije $(21,25 \%)$, potom računalni programi, igre i novi mediji $(17,50 \%)$ i umjetnost $(17,50 \%)$.

\subsection{Analiza rezultata istraživanja i diskusija}

Preliminarne analize. Kako bi se utvrdilo zadovoljava li uzorak sve uvjete za regresijsku analizu, proveden je niz preliminarnih analiza koje su uključivale analizu ekstremnih vrijednosti, testove normalnosti te nužne transformacije varijabli. Analizom ekstremnih vrijednosti utvrđene su višestruke ekstremne vrijednosti u odgovorima triju ispitanika koji su potom izuzeti iz daljnjih analiza. Za analizu normalnosti distribucija korišten je Shapiro-Wilk test (S-W test). Sve $p$-vrijednosti S-W testa su manje od 0,05 što upućuje na odbacivanje hipoteze o normalnosti te je provedena transformacija podataka logaritamskom funkcijom kako bi se normalizirale distribucije.

Regresijska analiza. Rezultati provedene višestruke linearne regresijske analize upućuju da utjecaj orijentacije na proizvod i orijentacije na kupca na inovativnost proizvoda za kupca nije statistički značajan, stoga se regresijski koeficijenti dalje ne interpretiraju. Ovakav rezultat može se objasniti i relativno malim uzorkom istraživanja te se može očekivati statistički značajan rezultat ukoliko je istraživanje provedeno na većem uzroku (Tabachnik i Fidell, 2007.). Suprotno ovom rezultatu, Atuahene-Gima (1996.) nalaze statistički značajan negativan utjecaj orijentacije na kupca na inovativnost za potrošača. Drugim riječima, veća orijentacija prema kupcu dovodi do manje percipirane inovativnosti proizvoda za kupca te autor zaključuje da orijentacijom na kupca poduzeće smanjuje vjerojatnost da proizvede inovativan/radikalan proizvod koji zahtijeva učenje i velike promjene u ponašanju od strane kupaca. Također, Gatignon i Xuereb (1997.) zaključuju da je za razvoj superiornih inovacija nužna orijentacija na proizvod, što nije potvrđeno ovim istraživanjem. 
S druge strane, rezultati provedene višestruke linearne regresijske analize upućuju na statistički značajan utjecaj inovativnosti proizvoda za kupca na percipiranu uspješnost poduzeća $(F(1,78)=17,628, p<0,015)$, uz $R^{2}=0,073$ te prilagođeni $R^{2}=0,061$. Standardizirani koeficijenti prikazani su u Tablici 3. te upućuju na pozitivan, umjereno jak, statistički značajan utjecaj inovativnosti za kupca na uspješnost poduzeća $(\beta=0,271, p<0,015)$. Odnosno, što je proizvod za kupca inovativniji, te zahtijeva učenje i velike promjene u ponašanju od strane kupaca, to je veća i precipirana uspješnost poduzeća. Navedeni rezultat u skladu je s istraživanjem Gatignon i Xuereb (1997.) koji zaključuju da veći stupanj inovativnosti odnosno radikalnije inovacije proizvoda dovode do veće uspješnosti.

Tablica 3. Rezultati regresijske analize utjecaja inovativnosti za kupca na percipiranu uspješnost poduzeća

\begin{tabular}{|l|c|c|c|c|c|}
\cline { 2 - 5 } \multicolumn{2}{c|}{} & \multicolumn{2}{|c|}{$\begin{array}{c}\text { Nestandardizirani } \\
\text { koeficijenti }\end{array}$} & Standardizirani koeficijenti & \multirow{2}{*}{ Sig. } \\
\cline { 2 - 4 } & $\mathrm{B}$ & Std. Error & Beta & & \\
\hline 1 & 5.474 & .887 & .271 & 6.173 & .000 \\
\hline $\begin{array}{l}\text { (Constant) } \\
\text { Inovativnost } \\
\text { proizvoda za } \\
\text { kupca }\end{array}$ & .079 & .032 & & .482 & .015 \\
\hline
\end{tabular}

Izvor: obrada autorica (SPSS).

Naposljetku, provedena linearna regresijska analiza upućuje na statistički značajan utjecaj orijentacije na proizvod i orijentacije na kupca na percipiranu uspješnost poduzeća $(F(2,77)=13,816, p<0,000)$, uz $R^{2}=0,264$ te prilagođeni $R^{2}=0,245$. Standardizirani koeficijenti prikazani su u Tablici 4. te upućuju na pozitivan, jak, statistički značajan utjecaj orijentacije na kupca na uspješnost poduzeća $(\beta=0,509, p<0,000)$, dok utjecaj orijentacije na proizvod nije statistički značajan. Ovaj rezultat je u skladu s istraživanjem Gatignon i Xuereb (1997.) prema kojima orijentacija na kupca omogućava poduzeću da inovaciju postavi na tržište s više uspjeha, pogotovo kada se radi o inkrementalnim inovacijama. Međutim, također ističu da poduzeća trebaju kombinirati orijentaciju na kupca i orijentaciju na proizvod kako bi postigli veću uspješnost poduzeća u situacijama nesigurne potražnje na tržištu. Slične rezultate navode i Camarero i Garrido (2008.) prema kojima i orijentacija na

Tablica 4. Rezultati regresijske analize utjecaja orijentacije na proizvod i orijentacije na kupca na percipiranu uspješnost poduzeća

\begin{tabular}{|c|c|c|c|c|c|c|}
\hline \multirow{2}{*}{\multicolumn{2}{|c|}{ Model }} & \multicolumn{2}{|c|}{$\begin{array}{l}\text { Nestandardizirani koefi- } \\
\text { cijenti }\end{array}$} & \multirow{2}{*}{$\begin{array}{c}\text { Standardizirani koeficijenti } \\
\text { Beta } \\
\end{array}$} & \multirow[t]{2}{*}{$\mathrm{t}$} & \multirow[t]{2}{*}{ Sig. } \\
\hline & & B & Std. Error & & & \\
\hline \multirow{3}{*}{1} & (Constant) & 4.522 & .790 & & 5.725 & .000 \\
\hline & $\begin{array}{l}\text { Orijentacija } \\
\text { na proizvod }\end{array}$ & .031 & .108 & .029 & .291 & .772 \\
\hline & $\begin{array}{l}\text { Orijentacija } \\
\text { na kupca }\end{array}$ & .296 & .057 & .509 & 5.157 & .000 \\
\hline
\end{tabular}

Izvor: obrada autorica (SPSS). 
proizvod i orijentacija na kupca doprinose uspješnosti poduzeća. Naposljetku, rezultat je u suprotnosti s rezultatima Voss i Voss (2000.) prema kojima orijentacija na proizvod ima blagi pozitivan utjecaj na broj pretplatnika kazališnih predstava, dok orijentacija na kupca ima negativan utjecaj na broj pretplatnika, kao i na percipiranu financijsku uspješnost kazališta.

Rezultati istraživanja samo su djelomice u skladu s prethodnim istraživanjima iz ovog područja. Suprotno očekivanjima, niti orijentacija na kupca niti orijentacija na proizvod nemaju statistički značajan utjecaj na percipiranu inovativnost proizvoda za kupca. Razlog za takav rezultat može se opravdati i manjim uzorkom, ali i razlikama u strukturi uzorka. Naime, među rijetkim radovima koji istražuju utjecaj strateške orijentacije u KKI, autori su se fokusirali isključivo na jedan pod-sektor. Konkretno, Voss i Voss (2000.) se fokusiraju na kazališnu industriju dok se Camarero i Garrido (2008.) fokusiraju na muzeje, dok je ovo istraživanje uzelo u obzir sva poduzeća koja djeluju u sklopu KKI, pri čemu su najzastupljeniji bili oglašavanje i tržišne komunikacije te računalni programi, igre i novi mediji. Veliku ulogu također mogu igrati i kulturološke razlike i razlike u stupnju razvijenosti tržišta na kojem ta poduzeća odnosno organizacije djeluju.

\section{ZAKLJUČAK}

\subsection{Implikacije za teoriju i praksu}

Implikacije za praksu s obzirom na prethodno prikazane rezultate istraživanja su dvojake. Prvo, ovaj rad pokazuje važnost razumijevanja strateške orijentacije koja se primjenjuje u organizaciji te njenog doprinosa ukupnoj uspješnosti poduzeća koja djeluju unutar KKI. Konkretno, istraživanje je pokazalo da orijentacija na kupca ima jak, značajan i pozitivan utjecaj na uspješnost poduzeća u KKI. Zanimljivo, ispitanici su u ovom istraživanju ocijenili svoja poduzeća kao više orijentirana na proizvod, nego na kupca. Sukladno tome, glavna preporuka za poduzeća koja djeluju u sklopu KKI je da osim jakog fokusa na proizvod, svakako trebaju uložiti značajne napore u razumijevanje želja i potreba svojih sadašnjih i potencijalnih kupaca ako žele uspjeti na tržištu. Navedeno može uključivati i značajnija i sustavnija ulaganja u različite oblike istraživanja tržišta s ciljem boljeg razumijevanja želja i potreba potrošača u ranijim fazama razvoja novih proizvoda, ali i u fazi testiranja prototipa te praćenju zadovoljstva kupaca. Drugo, istraživanje je pokazalo da percipirana inovativnost za kupca ima umjeren pozitivan utjecaj na uspješnost poduzeća. Dakle, poduzeća trebaju stremiti prema razvoju proizvoda koji po svojim karakteristikama od kupaca zahtijevaju više truda i razumijevanja funkcionalnosti, prednosti i koristi koje novi proizvod nudi, jer se na taj način taj proizvod može diferencirati od ostalih, konkurentskih proizvoda na tržištu. Ipak, primjena navedenog znatno će ovisiti i o karakteristikama tržišta na kojem samo poduzeće djeluje.

\subsection{Ograničenja i preporuke za buduća istraživanja}

Postoji nekoliko ograničenja istraživanja koja su utjecala na konačne rezultate, temeljem kojih se mogu dati i specifične preporuke za buduća istraživanja. Prvo ograničenje odnosi se na veličinu i strukturu uzorka. Naime, promatrajući strukturu uzorka vidljivo je kako je preko $70 \%$ ispitanika u dobnoj skupini od 25 do 34 godine. Kada promatramo 
rezultate prema vrsti djelatnosti, dominira djelatnost oglašavanja i tržišnih komunikacija $(21,25 \%)$, zatim računalni programi, igre i novi mediji $(17,50 \%)$ te djelatnost umjetnosti $(17,50 \%)$ dok je preostalih osam djelatnosti zastupljeno u vrlo malenom postotku. Sukladno tome, uzorak nije reprezentativan te se zaključci istraživanja ne mogu generalizirati za cijelu KKI u Republici Hrvatskoj. Detaljnom analizom strukture uzorka, preporuka je za buduća istraživanja povećati broj ispitanika u uzorku te osigurati podjednaku zastupljenost ispitanika iz svih pod-sektora KKI, što može dovesti do novih saznanja vezanih uz odnos strateške orijentacije i uspješnosti ovisno o pod-sektoru te o veličini poduzeća. Navedeno bi također omogućilo korištenje i primjenu drugih metoda analize poput modeliranja strukturnih jednadžbi za utvrđivanje odnosa između varijabli u modelu. Drugo ograničenje odnosi se na metodu prikupljanja podataka elektroničkim putem. Iako navedena metoda ima svoje prednosti, jedan od važnijih nedostataka je nemogućnost direktne motivacije ispitanika na sudjelovanje ili pojašnjavanja pojedinih složenijih pitanja (Aaker et al., 2016.). Sukladno navedenom, preporuka je provesti istraživanje korištenjem CATI metode. Treće ograničenje odnosi se na korištenje isključivo subjektivnih mjera uspješnosti poduzeća. U tom kontekstu, preporuka za buduća istraživanja jest korištenje kako objektivnih mjera (Voss i Voss, 2000.), ali i drugih, neekonomskih mjera uspješnosti s obzirom na specifičnosti KKI. Navedena preporuka je u skladu sa zaključcima Camarero i Garrido (2008.), koji osim ekonomskih mjera uspješnosti zagovaraju korištenje društvenih mjera uspješnosti s obzirom na činjenicu da je jedan od ciljeva kulturnih organizacija diseminacija kulture te promocija pozitivnog stava prema kulturi. Vezano uz navedeno, preporuča se i korištenje vremenskog odmaka u odnosu na konačnu zavisnu varijablu kako bi se moglo utvrditi postojanje kauzalnosti.

Naposljetku, iako se u ovom radu promatra utjecaj dviju strateških orijentacija na inovativnost za potrošača i uspješnost poduzeća, jačina navedenog utjecaja može ovisiti i o nizu drugih čimbenika. Konkretno, uz navedene dvije orijentacije, promatran je i utjecaj inovativnosti proizvoda za kupca na percipiranu uspješnost poduzeća, koji, zbog male eksplanatorne snage regresijskog modela $\left(\mathrm{R}^{2}=0,073\right)$ upućuje na niz drugih varijabli poput stupnja inovativnosti proizvoda iz perspektive poduzeća (Gatignon i Xuereb, 1997.), karakteristikama poduzeća (proizvodna ili uslužna poduzeća, poduzeća koja djeluju na tržištu krajnje ili poslovne potrošnje, korporativna kultura poduzeća i sl.), karakteristikama tržišta (razvijenost tržišta, stupanj konkurentnosti na tržištu i sl.) koja se mogu uzeti u obzir za buduća istraživanja. Uz navedeno, preporučuje se u buduće modele uključiti i kontrolne varijable na razini strateške poslovne jedinice, poduzeća ili industrije koje mogu dodatno objasniti varijancu percipirane uspješnosti poduzeća (vidjeti i Gatignon i Xuereb, 1997.).

\section{POPIS IZVORA}

1. $\quad$ Aaker, David A.; Kumar, V.; Leone, Robert P.; Day, George S.. (2016.). Marketing Research, Hoboken, NJ: John Wiley \& Sons, Inc.

2. Alvarez, J. L., Mazza, C., Pedersen, J. S. i Svejenova, S. (2005.). Shielding idiosyncrasy from isomorphic pressures: Towards optimal distinctiveness in European filmmaking. Organization, 12(6), 863-888. 
3. Atuahene-Gima, K. (1995.). An exploratory analysis of the impact of market orientation on new product performance: a contingency approach. Journal of Product Innovation Management: an international publication of the product development \& management association, 12(4), 275-293.

4. Atuahene-Gima, K. (1996.). Market orientation and innovation. Journal of business research, 35(2), 93-103.

5. Božić, L. (2006.). Učinci sastavnica tržišne orijentacije na razvoj inovacija proizvoda. Privredna kretanja i ekonomska politika, 16(107), 46-63.

6. Camarero, C. i Garrido, M. J. (2008.). The influence of market and product orientation on museum performance. International Journal of Arts Management, 10(2), 14-26.

7. Christensen, C. M. i Bower, J. L. (1996.). Customer power, strategic investment, and the failure of leading firms. Strategic management journal, 17(3), 197-218.

8. Cooper, C. (Ed.) (1994.). Technology and innovation in the international economy. United Nations University Press.

9. DCMS (1998.). Creative industries mapping document. DCMS London.

10. DCMS (2001.). Creative industries mapping document, 2007. London.

11. Deshpandé, R., Farley, J. U. i Webster Jr, F. E. (1993.). Corporate culture, customer orientation, and innovativeness in Japanese firms: a quadrad analysis. Journal of marketing, 57(1), 23-37.

12. De Vany, A. S. i Walls, W. D. (2004.). Motion picture profit, the stable Paretian hypothesis, and the curse of the superstar. Journal of Economic Dynamics and Control, 28(6), 1035-1057.

13. Eliashberg, J. i Robertson, T. S. (1988.). New product preannouncing behavior: A market signaling study. Journal of Marketing Research, 25(3), 282-292.

14. Gatignon, H. i Xuereb, J. M. (1997). Strategic orientation of the firm and new product performance. Journal of marketing research, 34(1), 77-90.

15. Han, J. K., Kim, N., i Srivastava, R. K. (1998.). Market orientation and organizational performance: is innovation a missing link?. Journal of marketing, 62(4), 30-45.

16. Hesmondhalgh, D. (2008). Cultural and creative industries.

17. Hrvatski klaster konkurentnosti kreativne i kulturne industrije (2013.) Strateške smjernice za razvoj Kreativne i kulturne industrije. Zagreb: HKKKKI

18. Hult, G. T. M. i Ketchen Jr, D. J. (2001.). Does market orientation matter?: A test of the relationship between positional advantage and performance. Strategic management journal, 22(9), 899-906.

19. Jaworski, B. J. i Kohli, A. K. (1993.). Market orientation: antecedents and consequences. Journal of marketing, 57(3), 53-70.

20. S. Jovičić, H. Mikić (2006.). Kreativne industrije u Srbiji, BRITISH COUNCIL, Terazije 8/I, Beograd, Srbija i Crna Gora.

21. Kirca, A. H., Jayachandran, S. i Bearden, W. O. (2005.). Market orientation: A meta-analytic review and assessment of its antecedents and impact on performance. Journal of marketing, 69(2), 24-41. 
22. Kohli, A. K. i Jaworski, B. J. (1990.). Market orientation: the construct, research propositions, and managerial implications. Journal of marketing, 54(2), 1-18.

23. Kohli, A. K., Jaworski, B. J. i Kumar, A. (1993.). MARKOR: a measure of market orientation. Journal of Marketing research, 30(4), 467-477.

24. MacKenzie, S. B., \& Podsakoff, P. M. (2012). Common method bias in marketing: Causes, mechanisms, and procedural remedies. Journal of retailing, 88(4), 542-555.

25. Mapiranje kreativnih i kulturnih industrija u Republici Hrvatskoj, Ekonomski Institut Zagreb, Zagreb, lipanj 2015.

26. Martin, C. L. (1995.). The customer compatibility scale: measuring service customers' perceptions of fellow customers. Journal of Consumer Studies \& Home Economics, 19(3), 299-311.

27. Matsuno, K. i Mentzer, J. T. (2000.). The effects of strategy type on the market orientation-performance relationship. Journal of marketing, 64(4), 1-16.

28. Narver, J. C. i Slater, S. F. (1990.). The effect of a market orientation on business profitability. Journal of marketing, 54(4), 20-35.

29. Noble, C. H., Sinha, R. K. i Kumar, A. (2002.). Market orientation and alternative strategic orientations: a longitudinal assessment of performance implications. Journal of marketing, 66(4), 25-39.

30. Nunnally, J. C. (1994.). Psychometric theory 3E. Tata McGraw-hill education.

31. Peltoniemi, M. (2015.). Cultural industries: Product-market characteristics, management challenges and industry dynamics. International journal of management reviews, 17(1), 41-68.

32. Porter, M. E. (1985.). Technology and competitive advantage. The Journal of Business Strategy, 5(3), 60.

33. Pratt, A. C. (2008.). Creative cities: the cultural industries and the creative class. Geografiska annaler: series B, human geography, 90(2), 107-117.

34. Primorac, J. (2012.). Od nesigurnosti do nesigurnosti: rad i zaposlenost u kulturnim i kreativnim industrijama. Revija za sociologiju, 42(1), 5-30.

35. Rune, T. N. L. i Volante, Q. N. B. (2010.). Creative Economy Report 2010.

36. Shapiro, B. P. (1988.). What the hell is market oriented? (pp. 1-3). HBR Reprints.

37. Slater, S. F. i Narver, J. C. (1994.). Market orientation, customer value, and superior performance. Business horizons, 37(2), 22-28.

38. Slater, S. F. i Narver, J. C. (1999.). Market-oriented is more than being customerled. Strategic management journal, 20(12), 1165-1168.

39. Tabachnick, B. G., Fidell, L. S. i Ullman, J. B. (2007.). Using multivariate statistics (Vol. 5, pp. 481-498). Boston, MA: Pearson.

40. Throsby, D. (2003.). Determining the value of cultural goods: How much (or how little) does contingent valuation tell us?. Journal of cultural economics, 27(3-4), 275285.

41. Towse, R. (2003.). 20 Cultural industries. A handbook of cultural economics, 170.

42. Voss, G. B. i Voss, Z. G. (2000.). Strategic orientation and firm performance in an artistic environment. Journal of marketing, 64(1), 67-83. 


\section{PRILOZI}

Prilog 1. Pod-sektori kreativnih i kulturnih industrija prema NKD-u 2007.

\begin{tabular}{|c|c|c|}
\hline Pod-sektori KKI & NKD 2007 & Naziv djelatnosti \\
\hline \multirow{3}{*}{$\begin{array}{l}\text { Muzeji, knjižnice i } \\
\text { baština }\end{array}$} & 91.01 & Djelatnosti knjižnica i arhiva \\
\hline & 91.02 & Djelatnosti muzeja \\
\hline & 91.03 & Rad povijesnih mjesta i građevina te sličnih zanimljivosti za posjetitelje \\
\hline \multirow[t]{3}{*}{ Umjetnost } & 90.03 & Umjetničko stvaralaštvo \\
\hline & 90.04 & Rad umjetničkih objekata \\
\hline & 85.52 & Obrazovanje i poučavanje u području kulture \\
\hline \multirow{8}{*}{$\begin{array}{l}\text { Glazba i izvedbene } \\
\text { umjetnosti }\end{array}$} & 18.20 & Umnožavanje snimljenih zapisa \\
\hline & 59.20 & Djelatnosti snimanja zvučnih zapisa i izdavanja glazbenih zapisa \\
\hline & 47.63 & Trgovina na malo glazbenim i videozapisima u specijaliziranim prodavaonicama \\
\hline & 85.52 & Obrazovanje i poučavanje u području kulture \\
\hline & 32.20 & Proizvodnja glazbenih instrumenata \\
\hline & 77.39 & Iznajmljivanje i davanje u zakup (leasing) ostalih strojeva, opreme i materijalnih \\
\hline & 90.01 & Izvođačka umjetnost \\
\hline & 90.02 & Pomoćne djelatnosti u izvođačkoj umjetnosti \\
\hline Dizajn & 74.10 & Specijalizirane dizajnerske djelatnosti \\
\hline \multirow[t]{5}{*}{ Film } & 59.11 & Proizvodnja filmova, video-filmova i televizijskog programa \\
\hline & 59.12 & Djelatnosti koje slijede nakon proizvodnje filmova, video-filmova i televizijskog \\
\hline & 59.13 & Distribucija filmova, video-filmova i televizijskog programa \\
\hline & 59.14 & Djelatnosti prikazivanja filmova \\
\hline & 77.22 & Iznajmljivanje videokaseta i diskova \\
\hline Fotografija & 74.20 & Fotografske djelatnosti \\
\hline \multirow{7}{*}{$\begin{array}{l}\text { Zanati (umjetnički i } \\
\text { tradicijski obrti) }\end{array}$} & 15.12 & Proizvodnja putnih i ručnih torba i slično, sedlarskih i remenarskih proizvoda \\
\hline & 16.29 & Proizvodnja ostalih proizvoda od drva, proizvoda od pluta, slame i pletarskih materijala \\
\hline & 23.41 & Proizvodnja keramičkih proizvoda za kućanstvo \\
\hline & 23.49 & Proizvodnja ostalih proizvoda od keramike \\
\hline & 32.12 & Proizvodnja nakita i srodnih proizvoda \\
\hline & 32.13 & Proizvodnja imitacije nakita(bižuterije) i srodnih proizvoda \\
\hline & 32.20 & Proizvodnja glazbenih instrumenata \\
\hline Arhitektura & 71.11 & Arhitektonske djelatnosti \\
\hline \multirow{2}{*}{$\begin{array}{l}\text { Računalni programi, } \\
\text { igre i novi mediji }\end{array}$} & 58.21 & Izdavanje računalnih igara \\
\hline & 62.01 & Računalno programiranje ${ }^{\star}$ \\
\hline \multirow[t]{3}{*}{ Elektronički mediji } & 60.10 & Emitiranje radijskog programa \\
\hline & 60.20 & Emitiranje televizijskog programa \\
\hline & 63.12 & Internetski portali \\
\hline \multirow[t]{8}{*}{ Izdavaštvo } & 58.11 & Izdavanje knjiga \\
\hline & 58.13 & Izdavanje novina \\
\hline & 58.14 & Izdavanje časopisa i periodičnih publikacija \\
\hline & 58.19 & Ostala izdavačka djelatnost \\
\hline & 63.91 & Djelatnosti novinskih agencija \\
\hline & 74.30 & Prevoditeljske djelatnosti i usluge tumača \\
\hline & 47.61 & Trgovina na malo knjigama u specijaliziranim prodavaonicama \\
\hline & 47.62 & $\begin{array}{l}\text { Trgovina na malo novinama, papimatom robom i pisaćim priborom u specijaliziranim } \\
\text { prodavaonicama* }\end{array}$ \\
\hline \multirow{3}{*}{$\begin{array}{l}\text { Oglašavanje i tržišno } \\
\text { komuniciranje }\end{array}$} & 70.21 & Odnosi s javnošću i djelatnosti priopćivanja \\
\hline & 73.11 & Agencije za promidžbu (reklamu i propagandu) \\
\hline & 73.12 & Oglašavanje preko medija \\
\hline
\end{tabular}

Napomena:*djelomično kreativne djelatnosti, ponder 0,5. Izvor: sistematizacija autorica

Izvor: Mapiranje kreativnih i kulturnih industrija u Republici Hrvatskoj, Ekonomski Institut Zagreb, Zagreb, lipanj 2015. 